\title{
Az MH Geoinformációs Támogatási Doktrína felülvizsgálata az újonnan rendszeresített technikai eszközök tükrében n.resz
}

\section{Bevezetés}

Doktori képzés keretében végzett kutatásomhoz ${ }^{1}$ kapcsolódóan jelen tanulmányomban azt vizsgálom meg, hogy egy geoinformációs értékelő-elemző rendszer kialakításához és megvalósításához milyen hazai és nemzetközi szabályozók, doktrínák állnak rendelkezésre a Magyar Honvédségben $(\mathrm{MH})$, ezek milyen mértékben felelnek meg a felmerülő követelményeknek, valamint a felülvizsgálat alatt álló MH Geoinformációs Támogatási Doktrína [1] új verziója képes-e biztosítani ennek szakmai hátterét.

A szakmai szabályozás, a jelenleg hatályos doktrína felülvizsgálata, megújítása elengedhetetlen annak érdekében, hogy az jobban illeszkedjen a NATO Térképészeti Irányelveihez [2] [3]. A doktrína megújítása az $\mathrm{MH}$ Geoinformációs Szolgálatánál (MH GEOSZ) folyamatban van, amelynek során a tervek szerint új, szabványos terminológiai jegyzék is készül, a 2019-ben kiadott Hadtudományi Lexikonnal [4] összhangban. Ebben a dokumentumban már megjelenik a mai kor szakmai feladatainak és lehetőségeinek megfelelő geoinformációs támogatás definíciója, a tér újszerű értelmezése is.

A magyar és angol nyelvű terminológiai források is úgy határozzák meg a doktrínát, hogy az a katonai erőket célkitűzéseik elérésében irányító alapelvek összessége, amely mérvadó dokumentum, de alkalmazásához szakmai ítélőképesség szükséges [5]. A doktrína kialakítása nem lehetőség, hanem kötelezettség. Egyben olyan dokumentum, ami nem elöírás, rugalmas szemléletet tükröz, mindig az adott helyzetre adaptálandó és segít az adott helyzethez

ÖSSZEFOGLALÁS: Jelenleg zajlik a 2014-ben kiadott Magyar Honvédség Geoinformációs Támogatási Doktrína felülvizsgálata, megújitása, a nemzeti sajátosságoknak, követelményeknek megfelelően biztosítva az EU, a NAT0 és a nemzetek közötti együttmúködéshez, a geoinformációs anyagok interoperabilitásának biztosításához szükséges feltételeket. Az MH doktrínafejlesztésének rövid áttekintése mellett a szerző bemutatja a doktrína átalakításának szakmai indokoltságát, és a gyakorlati felhasználást elősegítő racionalizálások lehetőségét, majd az általános felhasználáshoz kialakítandó doktrínán belül egy kiemelt gyakorlati példán keresztül röviden vázolja a biztonság- és védelemföldrajzi elemzéshez alkalmazható védelmi célú geoinformációs értékelő-elemző rendszer elvét. A tanulmány elkészítésének egyik célja annak vizsgálata, hogy a kialakítandó rendszer milyen lehetőségek mentén integrálható egy új támogatási doktrínába.

KULCSSZAVAK: geoinformáció, támogatás, doktrína, doktrínafejlesztés, felülvizsgálat történő alkalmazkodásban. A doktrína nem örök érvényű, a szakmai-technológiai változások, vagy a hadviselés természetének átalakulása indokolhatja a változást. A túl gyakori és radikális változtatások azonban aláássák a doktrína hitelét, megbízhatatlanná tehetik, így racionális egyensúlyra kell törekedni, tehát a legáltalánosabb és a legidőállóbb összefüggéseket kell feltárni úgy, hogy a doktrína mégis gyakorlatorientált maradjon [6].

\section{A BIZTONSÁG- ÉS VÉDELEMFÖLDRAJZI ELEMZÉSEKHEZ ALKALMAZHATÓ GEOINFORMÁCIÓS ÉRTÉKELŐ-ELEMZŐ RENDSZER ELVE}

A tér egy összetett kölcsönhatásrendszer, amelyben a földrajz által vizsgált jelenségek és folyamatok megjelennek. Ezeket a tényezőket a katonai tevékenység, a hadviselés szempontjából a katonaföldrajz elemzi, amely általánosan a földrajzi tér és a biztonságot fenyegető természetés társadalomföldrajzi tényezők és a fegyveres küzdelem kapcsolatát vizsgálja [4].

A katonaföldrajz fogalomköre az elmúlt évtizedben kibővült, a geoinformációs támogatás részeként többet, másképp vizsgál, mint előtte. A fogalomba beletartozik a természetföldrajz, és minden térbeli vetülettel rendelkező, kapcsolódó elem, így például jelentős a társadalmi viszonyok - napjainkban kiemelten a vallás -, az éghajlat elemzése, az időjárás vizsgálata, hiszen ezek szerepe a műveletekre gyakorolt hatásuk miatt megnőtt. A geoinformációs értékelés új értelmezése bővített térdefiníciót használ, vizsgálja a felszín alatti, a jóval a felszín feletti és a virtuális

ABSTRACT: The Geoinformation Support Doctrine the Hungarian Defense Forces (hereinafter referred to as HDF) issued in 2014 is currently being reviewed, in accordance with national specificities and requirements, ensuring the necessary conditions for cooperation between the EU and NATO nations, ensuring the interoperability of geoinformation materials. After a brief overview of the doctrine development of HDF, I present a professional justification of the necessary transformation of the doctrine and the possibility of rationalizations providing its use in practice. Within the doctrine to be developed for general use, through a key practical example, I briefly outline the principles of a geoinformation assessment and analysis system for security purposes that can be used for security and defense geographic analyses. One of my reasons to examine the doctrine is the integration of this planned system into it.

KEY WORDS: geospatial, support, doctrine, doctrine development, revision.

\footnotetext{
Alezredes, MH Geoinformációs Szolgálat Katonaföldrajzi és Szakkiképzési Osztály, osztályvezető, NKE HHK Hadtudományi Doktori Iskola, doktorandusz. ORCID: 0000-0002-0937-2770
} 
térben zajló folyamatokat is. A negyedik generációs hadviselés szempontjából nézve a műveletek már ezekben az új terekben is zajlanak, ezeket is szükséges a tér vizsgálatába és definíciójába foglalni.

A fegyveres küzdelem megvívásának mindig voltak objektív, mérhető katonaföldrajzi tényezői, amelyek feltérképezhetők, illetve adott célnak megfelelően felhasználhatók, így a térről gyűjtött információ szubjektív előnyt eredményezhet. Az ezeket az információkat leíró adatokat adatbázisban tároljuk, amelynek hatékony, a modern kor elvárásainak megfelelő felhasználására egy geoinformációs értékelő-elemző rendszer nyújthat segítséget. Az MH Geoinformációs Támogatási Doktrína revíziójakor figyelembe kell venni ennek a létrehozását is, érdemes olyan alapelveket megfogalmazni, amelyek általánosan megfelelnek a különböző geoinformációhoz kapcsolódó rendszerek alkalmazhatóságának. Amennyiben sor kerül rá, ennek szellemében kell az értékelő-elemző rendszert is fejleszteni, alkalmazni a jövőben.

\section{DoktrínafeJlesztés a Magyar HonvédséGben}

A védelmi politika, a stratégiai koncepciók és a doktrínák tartalma és jellege sok hasonlóságot, egymásra utaltságot, egyfajta hierarchiát mutat. A Nemzeti Biztonsági Stratégia határozza meg az ágazati stratégiákat, így a Nemzeti Katonai Stratégiát is azáltal, hogy a nemzeti célkitűzések közül az adott ágazat számára elérendő célokat rögzíti. A doktrínák hatékonyan elősegíthetik a stratégiák katonai részeinek, a katonai biztonsági céloknak a meghatározását. Jelenleg a Nemzeti Katonai Stratégia is megújítás alatt áll, így a megújuló doktrínában az ott megjelenő geoinformációs szakterületre ható változásokat is meg kell jeleníteni.

Magyarország katonai biztonsága reálisan csak szövetségi rendszerben értelmezhető. A NATO-tagállamok haderőinek hatékony együttműködése a geoinformációs támogatás területén is kiemelten fontos, tehát a nemzeti geoinformációs támogatási doktrínának is a NATO irányelvek figyelembevételével, a nemzeti sajátosságok és követelményekmentén kell megújulnia. ANATOÖsszhaderőnemi Térképészeti Támogatásra vonatkozó irányelvei a 2016ban kiadott MC 296/3 [2] és az AJP-3.17 [3] kiadványokban találhatók. Figyelemmel kell kísérni ez utóbbi jelenleg is zajló felülvizsgálatát. Az új irányelv² egyelőre tervezet formájában létezik, de a szakmai változásokat érdemes követni a hazai doktrína kidolgozása során is.

A Geoinformációs Támogatási doktrína megújítását két fő tényező indokolja: a szakmai-technológiai változások, a hadviselés természetének átalakulása, hiszen egy 2014-es kiadványról van szó, valamint a NATO irányelveinek felülvizsgálata, az annak való megfelelés a nemzeti sajátosságok megtartásával. A NATO doktrínafejlesztésének első lépése a doktrínarendszer hiányosságának felismerése [7].

\section{Doktrinális hierarchia a Magyar HonvédséGBen}

A Magyar Honvédségben a doktrinális hierarchia (1. ábra) felső szintjén az összhaderőnemi doktrína áll, amelynek rendeltetése a Nemzeti Katonai Stratégiában meghatározott elvek érvényre juttatása.

A második szinten helyezkednek el a törzsfunkciókat megjelenítő, átfogó jellegű doktrínák (felderítés, műveletek, logisztika, műveleti tervezés, híradó-informatika, kiképzés és stratégiai kommunikáció). A harmadik szinten pedig a szakmai doktrínák találhatók, így az MH Geoinformációs Támogatási Doktrína (MH DOFT ${ }^{3}$ kód: FD 2.4) is [8]. Külön vizsgálatot érdemel, hogy a Geoinformációs Támogatási Doktrína a jelenlegi struktúrában jó helyen van-e? Véleményem szerint egy szinttel magasabban, a második szinten lenne a helye, hiszen a geoinformációs támogatás nemcsak az összhaderőnemi műveletekben használatos, hanem szinte mindenhol: a felderítés, a logisztikai támogatás, a művelettervezés területén is.

\section{A MAGYAR DOKTRÍNAFEJLESZTÉS ELVE}

A magyar doktrínafejlesztést nem a szövetségi rendszer szabványai szabályozzák [8]. Hazánkban a szolgálati könyvek és a főnökségi kiadványok kiadásának rendjéről szóló 93/2006. (HK 18.) HM utasítás rendelkezik a doktrínafejlesztésről. A Magyar Honvédségben 2020 augusztusától a doktrinális fejlesztés irányítását az MH Transzformációs Parancsnokság Honvéd Kiválósági Központ koordinálja, és múködteti a Szabványosítási és Doktrinális Tanácsot $(\mathrm{MH}$ SZDT), amely az MH hivatalos véleményező, döntéshozó

1. ábra. A Magyar Honvédség doktrína hierarchiája, kiemelve a Geoinformációs támogatási doktrína helye a 2019-2022 DOFT alapján [9] (Forrás: a szerző szerkesztése)

\begin{tabular}{|c|c|c|c|c|}
\hline \multicolumn{5}{|c|}{ MH Összhaderönemi Doktrína (ÖHD) } \\
\hline $\begin{array}{c}\text { MH Kiképzési } \\
\text { MH Összhaderőnemi } \\
\text { Doktrína (KIKD 7) }\end{array}$ & $\begin{array}{l}\text { MH Összhaderönemi Müvelet- } \\
\text { tervezési Doktrína (MT 5) }\end{array}$ & $\begin{array}{ll}\text { derỏnemi } & \text { MH Összhaderônemi Hiradó és } \\
\text { Informatikai Doktrina (HID 6) }\end{array}$ & $\begin{array}{l}\text { MH Összhaderőnemi Logisztikai } \\
\text { Támogatás Doktrina (LOG D4) }\end{array}$ & $\begin{array}{l}\text { MH Összhaderönemi Stratégiai } \\
\text { Kommunikáció (SK 10) }\end{array}$ \\
\hline $\begin{array}{l}\text { Felderítő támogatás elvei } \\
\text { és gyakorlata doktrína (FD 2.1) }\end{array}$ & $\begin{array}{l}\text { Szárazö̈lldi müveletek } \\
\text { doktrína (MD 3.2) }\end{array}$ & $\begin{array}{l}\text { Légi müveletek } \\
\text { doktrína (MD 3.3) }\end{array}$ & $\begin{array}{l}\text { Közlekedési támogatás } \\
\text { doktrína (LOGD 4.4) }\end{array}$ & \\
\hline $\begin{array}{l}\text { Ellenséges hírszerzés-felderítés elleni } \\
\text { védelem és biztonsági doktrína (FD 2.2) }\end{array}$ & $\begin{array}{l}\text { Válságreagáló müveletek } \\
\text { doktrína (MD 3.4) }\end{array}$ & $\begin{array}{l}\text { Légi szállítási müveletek } \\
\text { doktrína (MD 3.3.4) }\end{array}$ & $\begin{array}{l}\text { Befogadó nemzeti támogatás } \\
\text { doktrína (LOGD 4.5) }\end{array}$ & \\
\hline $\begin{array}{r}\text { Harcászati hírszerző (HUMINT) } \\
\text { doktrína (FD 2.3) }\end{array}$ & $\begin{array}{l}\text { Különleges Müveleti } \\
\text { doktrína (MD 3.5) }\end{array}$ & $\begin{array}{l}\text { Összhaderőnemi elektronikai } \\
\text { hadviselés doktrína (MD 3.6) }\end{array}$ & $\begin{array}{l}\text { Összhaderőnemi egészségügyi } \\
\text { doktrína (LOGD 4.10) }\end{array}$ & \\
\hline $\begin{array}{l}\text { Elfogott személyek, zsákmányolt anyagok } \\
\text { és okmányok kezelése doktrína (FD 2.5) }\end{array}$ & $\begin{array}{l}\text { Összhaderönemi személyi } \\
\text { mentés doktrina (MD 3.7) }\end{array}$ & $\begin{array}{l}\text { Atom, biológiai, vegyi } \\
\text { védelmi doktrína (MD 3.8) }\end{array}$ & $\begin{array}{l}\text { Környezetvédelmi } \\
\text { doktrína (LOGD 4.13) }\end{array}$ & \\
\hline $\begin{array}{r}\text { Felderités és megfigyelés } \\
\text { doktrína (FD 2.7) }\end{array}$ & $\begin{array}{r}\text { Összhaderőnemi célkezelési } \\
\text { doktrína (MD 3.9) }\end{array}$ & $\begin{array}{l}\text { Információs müveletek } \\
\text { doktrína (MD 3.10) }\end{array}$ & & \\
\hline & $\begin{array}{r}\text { Geoinformációs támogatási } \\
\text { doktrína (MD 3.17) }\end{array}$ & $\begin{array}{l}\text { Lélektani műveletek } \\
\text { doktrína (MD 3.10.1) }\end{array}$ & & \\
\hline & $\begin{array}{l}\text { Összhaderőnemi civil-katonai } \\
\text { együttmüködési doktrína (MD 3.19) }\end{array}$ & $\begin{array}{l}\text { Kibervédelmi doktrína } \\
\text { (MD 3.20) }\end{array}$ & & \\
\hline
\end{tabular}


szerve doktrinális kérdésekben. A Magyar Honvédség doktrinális, szabványosítási és terminológiai tevékenységéről szóló 54/2015. (X. 21.) HM utasítás 3. § (3) bekezdése alapján az MH SZDT rendeltetése a NATO egységesítési egyezmények (STANAG ${ }^{4}$ ) feldolgozása, koordinálása, az $\mathrm{MH}$ Doktrína Hierarchiában (DH) és az MH Doktrína Fejlesztési Tervben előírt feladatok felső szintű irányítása, a hatályba léptetés előtt a nemzeti katonai doktrínák véleményezése és elfogadása.

A 2017-ben elkezdődött felülvizsgálati ciklusban a teljes doktrína-hierarchiát felül kell vizsgálni, és a felülvizsgálatoknak minden doktrína esetében négyévente meg kell ismétlődnie [9]. Az MH Geoinformációs Támogatási Doktrína hatályos verziójának felülvizsgálata szakmai okokból is szükséges.

A 2019-ben jóváhagyott DOFT lehetőséget ad a magyar doktrínarendszer részévé tenni a már elfogadott és bevezetett NATO-doktrínákat, a nemzeti fenntartás nélkül elfogadott és bevezetett NATO-doktrínák magyar fordításait ún. „lefordított doktrínaként” az $\mathrm{MH}$ DH részeivé tenni, amennyiben az adott területen nincs vonatkozó nemzeti doktrína [10]. Ez a módszer leegyszerűsíthetné az $\mathrm{MH}$ Geoinformációs Támogatási Doktrína kiadását, de a NATO Térképészeti Irányelveinek magyarra fordításával keletkező anyag nem minden részletében felelne meg a magyar nemzeti sajátosságoknak, így ez nem járható út, saját doktrínát kell fejleszteni.

\section{JAVASLAT ÚJ SZEMLÉLETŰ DOKTRÍNÁRA}

Mező András ${ }^{5}$ a magyar doktrínák és harcászati szabályzatok tanulmányozása után doktori disszertációjának tézisfüzetében [11] megállapítja, hogy az MH-ban az igényeknek megfelelő mennyiségű doktrína keletkezik, de azok nem mindig állnak összhangban a magyar doktrína-hierarchia egyes elemeivel és az alárendelt szabályzatokkal. Gondot jelent a NATO és a nemzeti doktrínáinak összehangolása is. Az MH Geoinformációs Támogatási Doktrína számos területen eltér a szakmailag irányadó NATO-irányelvektől, mivel az együttműködés biztosítása mellett a nemzeti szabályozás meghatározása a célja.

- Eltérések mutatkoznak a béke-, válságreagáló és háborús feladatok tárgyalásában - ezt a témát NATO Térképészeti Irányelve [2] nem tárgyalja külön, a hatályos magyar doktrína pedig még igen. Az MH Geoinformációs Szolgálat, mint irányító szerv és alárendeltjeinek feladatai doktrinális szinten nem változnak jelentős mértékben a készenlét fokozása esetén sem, így ennek a szétválasztásnak a megtartása nem indokolt.

- A NATO Térképészeti Irányelve a meteorológiát nem tárgyalja a támogatandó szakmai feladatok között, azt egy külön doktrínában tárgyalja [12]. A Magyar Honvédségben a meteorológiai támogatás az MH Geoinformációs Szolgálatnál valósul meg, így a meteorológia tárgyköre továbbra is - nemzeti sajátosságként - része marad a Geoinformációs Támogatási Doktrínának, de a jelenlegi tervek szerint önálló, fő fejezetet kap. A NATOban és a tagországokban is törekvés mutatkozik a GEO és a MET szakterületek összevonására.

- Ugyanígy nemzeti sajátosság a katonaföldrajzi támogatás kiemelése, ahol Magyarországra és az MH miszsziós érdekeltségi területére vonatkozóan készülnek szakmai háttéranyagok, leírások, ismertetők, értékelések. E dokumentumok megjelentetése a doktrínában szintén kiemelt fontosságú.
- A doktrínafejlesztés elengedhetetlen feltétele az egyezményes és szabványos terminológia használata [7]. Kerülendő a rokon értelmű szavak használata, az idegen kifejezések magyar tükörfordítása, vagy a nemzeti katonai kifejezések angolra fordítása, mert ezek nem mindig felelnek meg az egyértelmüség követelményének. A térképészet, meteorológia, katonaföldrajz - geoinformáció - területén a szakemberek különösen sok ilyen speciális magyar vagy nemzetközi szakkifejezést használnak. Elég csak a szakmai irányító szerv nevét adó geoinformáció fogalmára gondolni, ami nem egyenlő tartalmilag az angol geoinformation szóval, illetve az angol geospatial jelzőnek sincs egységesen bevett magyar szakmai fordítása. További nehézséget jelent, hogy a katonai szakszövegek fordítása magas fokú, speciális szaknyelvi ismeretet igényel, és természetesen nem elég lefordítani a szöveget, értelmezni is kell a tartalmát.

A terminológiai egységesítést segíti elő a 2015-ben megjelent Katonai terminológiai értelmező szótár a Zrínyi Kiadó kiadásában, illetve a geoinformáció (térképészet, katonaföldrajz, meteorológia) szakterületét tekintve főleg a 2019ben, a Dialóg Campus kiadásában megjelent Hadtudományi lexikon - Új kötet szakmai szócikkei [4].

Valamennyi NATO-doktrína melléklete tartalmazza az adott szakterület legfontosabb kifejezéseit és azok meghatározását, a rövidítéseket és azok jelentését. $\mathrm{Az} M \mathrm{MH}$ Geoinformációs Támogatási Doktrína felülvizsgálatának is része a terminológia megújítása, és mellékletbe rendezése, amely a tervek szerint tartalmazza mind a magyar mind az angol szakkifejezéseket, rövidítéseket.

\section{ÚJ TECHNIKAI ESZKÖZÖK}

A doktrína előző kiadása óta új technikai eszközök jelentek meg, illetve jelentették be hivatalosan a hadrendbe állításukat a Magyar Honvédségben. Ezeknek a geoinformációs támogatása, illetve a szakmai fejlődés kiszolgálása szintén olyan elem, amelynek a doktrínában meg kell jelennie. Fontos az egységes térinformatikai formátum használatának kiemelése, NATO-szabványok, adatmodellek alkalmazása, a szimulációs eszközök geoinformációs támogatása. Doktori kutatásom témája, egy biztonság- és védelemföldrajzi elemzéshez alkalmazható geoinformációs értékelő-elemző rendszer alkalmazási feltételeinek megteremtése, amihez - más rendszerekhez ${ }^{6}$ hasonlóan - a doktrína adhat szabályozási keretet.

Lássunk most néhány példát a Zrínyi Honvédelmi és Haderőfejlesztési Program keretében beszerzésre került haditechnikai eszközökből, amelyek indokolják az MH Geoinformációs Támogatási Doktrína megújítását. Természetesen a doktrína feladata általánosságban, és hosszú távon segíteni a jelenleg és a jövőben hadrendbe állítandó eszközök geoinformációs támogatását, tehát az itt kiemelt harceszközök csak példák, a teljesség igénye nélkül. A hazánk által beszerzett eszközök közül a Leopard 2A7-es harckocsi, a Lynx KF41 gyalogsági harcjármű, az Airbus H145M könnyü, többcélú helikopter és az Iron Dome (Vaskupola) izraeli rakétavédelmi rendszer „lelkét” jelentő EL/M-2084 aktív elektronikus fázisvezérelt radarok geoinformációs támogatásban is változást hozó technikai újításainak egy részét mutatom be.

\section{A LEOPARD 2A7-ES HARCKOCSI}

A harckocsi tornyába épített tűzvezető rendszerek biztosítják a pontos célzást, így az képes mozgás közben olyan 


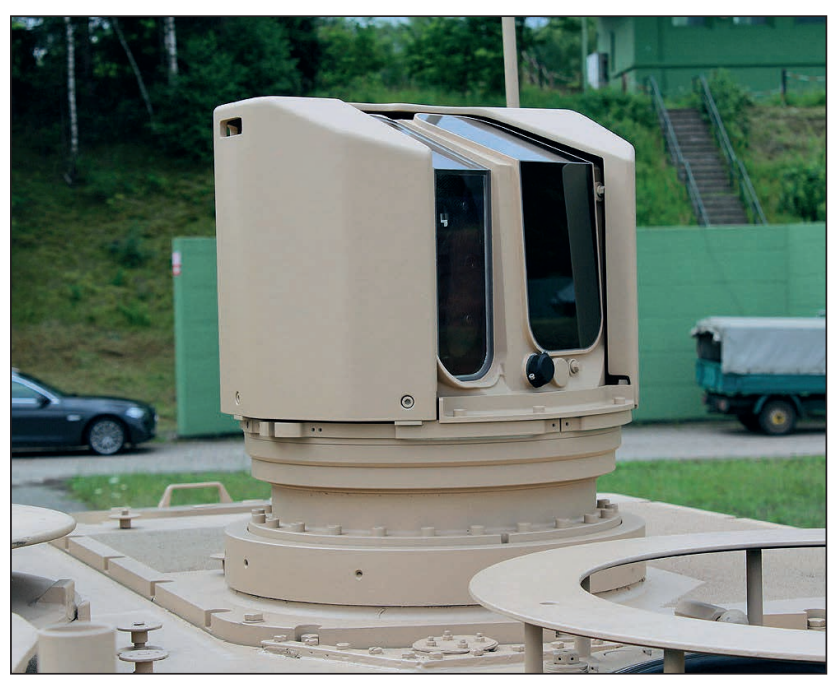

2. ábra. A Leopard 2A7-es harckocsi digitális parancsnoki periszkópja [13]

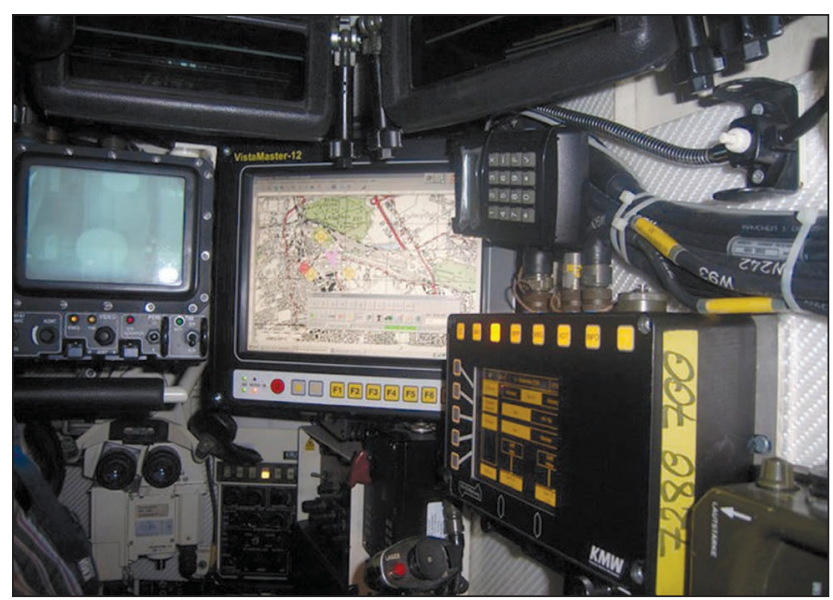

3. ábra. A Leopard 2A7 harckocsi belső tere [17]

célok leküzdésére, amelyek maguk is mozognak. A jármüben elhelyezett EMES-15 tűzvezető rendszer optikájának fejlesztése érdekében a CMT Zeiss WBG-X hő/infrakameráját lecserélik az Attica GL hő- és optikai kamerára, amely ötvenszeres optikai zoomot biztosít, és amelyet ezután nyolcszorosra lehet digitálisan nagyítani a folyamatos négyszázszoros zoom elérése érdekében.

Az IBD Deisenroth és a Rheinmetall vállalatok további fontos fejlesztése az ADS (Active Defence System - aktív védelmi rendszer), amely számos optikai érzékelőt, $360^{\circ}$-os szögben körbe forgó kamerát alkalmaz a harcjárművet fenyegető támadások előrejelzésére. (2-3. ábra.)

A parancsnok a Rheinmetall/Zeiss PERI R-17A2 optikai rendszerével figyelheti meg a környezetét. A periszkóp stabilizált, éjszakai megfigyelésre és célmegjelölésre egyaránt alkalmas. Funkciójának és kialakításának köszönhetően a PERI R-17A2 könnyen integrálható a tűzvédelmi rendszerekbe. A látható és az infravörös spektrális tartományokban is használható. A célzókészüléknek az alábbi adatokat kell ismernie, hogy pontosan kiszámítsa a lövés irányát: a cél és a saját eszköz térbeli elhelyezkedése, mozgási vektora (irány, sebesség), saját lőszertípusa, a szél sebessége, a légnyomás értéke, a levegő hőmérséklete. [14] Ezen adatok közül a helyzeti, az irány és távolság, valamint az időjárási adatokra vonatkozó ismeretek geoinformációs adatok.

\section{A LYNX KF41 GYALOGSÁGI HARCJÁRMÚ}

A 2018-ban bemutatott Lynx KF41 gyalogsági harcjármüvet a tervek szerint a Magyar Honvédség rendszerbe állítja, ezért 218 db-ot rendelt, amelyből 172 db-ot hazánkban fognak gyártani. A szerződés aláirására és bejelentésére 2020. augusztus 17-én került sor Unterlüsben, a Rheinmetall vállalat székhelyén. Ezzel a szerződéssel Magyarország lesz a KF41 harcjármű első megrendelője és egyben gyártója is, hiszen a szerződéskötés bejelentését követte az eszközök gyártását végző zalaegerszegi központ zöldmezős beruházás keretében történő kialakítására kötendő megállapodás aláírása is. [15] A Lynx tornyába épített optronikai és tűzvédelmi rendszer (FCS - Fire Control System) fő elemei a következők [16]:

- Stabilizált elektro-optikai érzékelőrendszer (SEOSS Stabilised Electro-Optical Sensor System) visszahúzható panorámás beépített lézeres távolságmérővel;

- A SEOSS szektorfigyelő a fő fegyverzethez integrált lézeres távolságmérővel;

- Lézer(besugárzás) érzékelő rendszer (LWS - Laser Warning System);

- Akusztikus lövés-lokátor rendszer (ASLS - Acoustic Shooter Locating System)

- Nappali / éjszakai látást és automatikus célfelismerést magában foglaló helyzetfelismerési rendszer (SAS Situational Awareness System);

- Vezérlőfogantyú;

- Videó feldolgozó és terjesztő egység.

Az FCS-rendszer lehetővé teszi, hogy a jármű személyzete, annak elhagyása nélkül, éjjel-nappal korlátlanul képes legyen a célok felismerésére és azonosítására, valamint a folyamatos megfigyelésre. (4. ábra.) Az érzékelők által szolgáltatott nagy tömegű információ egy része szintén a geoinformációs adatok körébe tartozik.

\section{4. ábra. Lynx KF41, SEOSS stabilizált elektro-optika} érzékelörendszerek a tornyon [16]

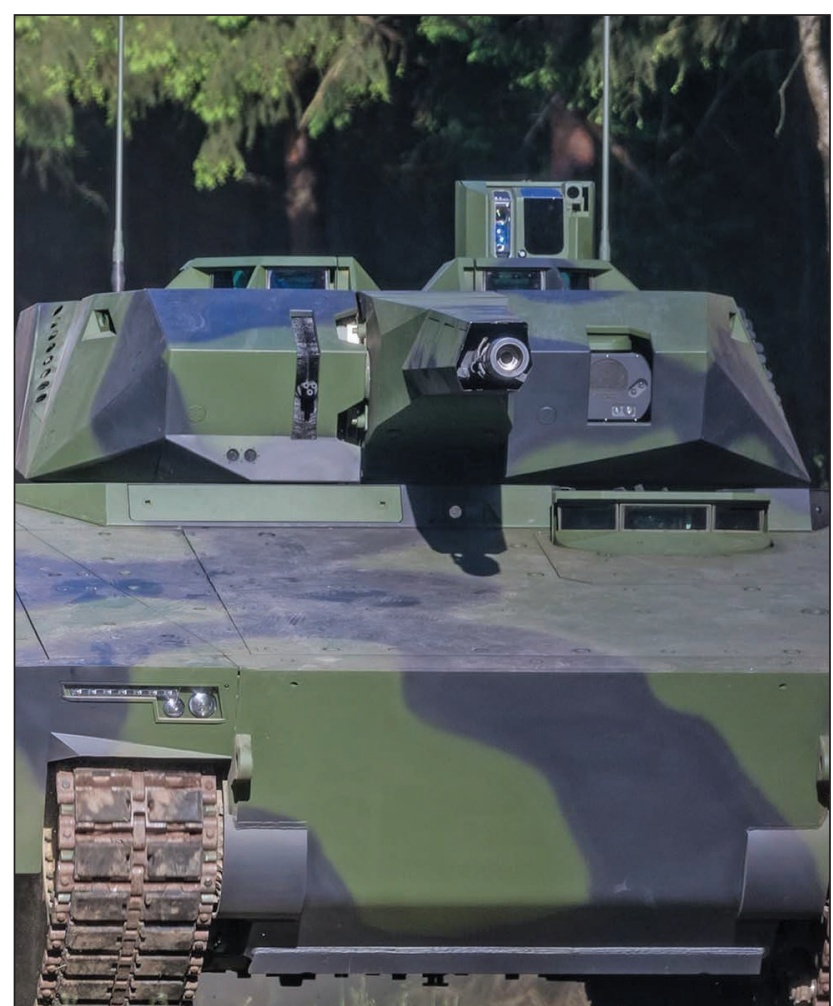




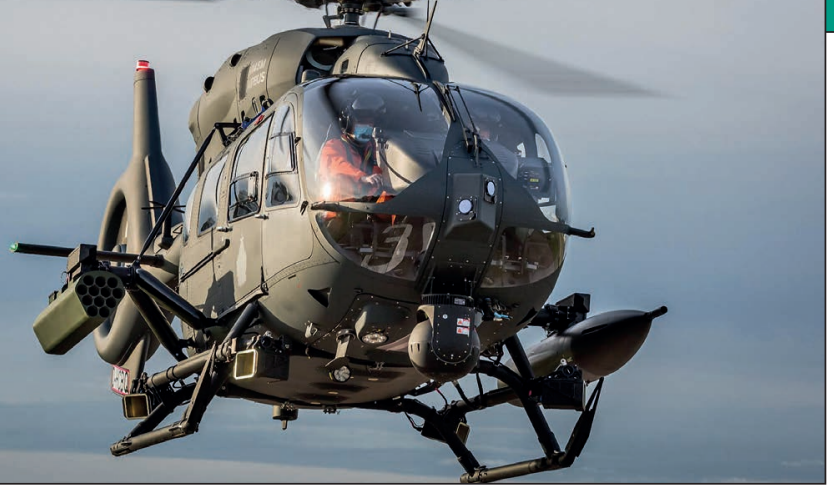

5. ábra. Magyar H145M helikopter kiképzörepülés közben [19]

\section{Az AlRBus H145M KÖNNYÜ, tÖBBCÉLÚ HELIKOPTER}

A H145M helikopterek rendszerbe állításával a hazai katonai repülésben technológiai korszakváltás is történt. $A z$ eddig alkalmazott analóg műszerekkel rendelkező helikopterek után, jelentős előrelépést hozott a digitális technikai megoldásokkal működtetett légi járművek üzemeltetése. A helikopter fedélzeti vezérlőrendszere részben a Helionix rendszerre épül, amely hozzáférést biztosít a hajózók számára a helikopter fedélzeti rendszereihez, megadja a repüléshez szükséges információkat, mint például a sebesség, a magasság, a függőleges emelkedés vagy süllyedés, és az irányszög. Ebbe a rendszerbe integrálták a tereppel, illetve a más légi járművekkel történő összeütközésre figyelmeztető rendszereket is, de lehetőség nyílik digitális domborzatmodell megjelenítésére, illetve külső kamerarendszeren keresztül történő megfigyelésre [18] is. (5. ábra.)

A H145M helikopter navigációt segítő felszereltsége két intelligens $6 \times 8$ hüvelykes, multifunkciós képernyőből álló repülési kijelző alrendszer (FDS - Flight Display Subsystem) [20]. Ennek része a repülési navigációs kijelző (FND - Flight Navigation Display), beleértve a magassági és sebességadatokat megjelenítő elsődleges képernyőt (PFD - Primary Flight Display).

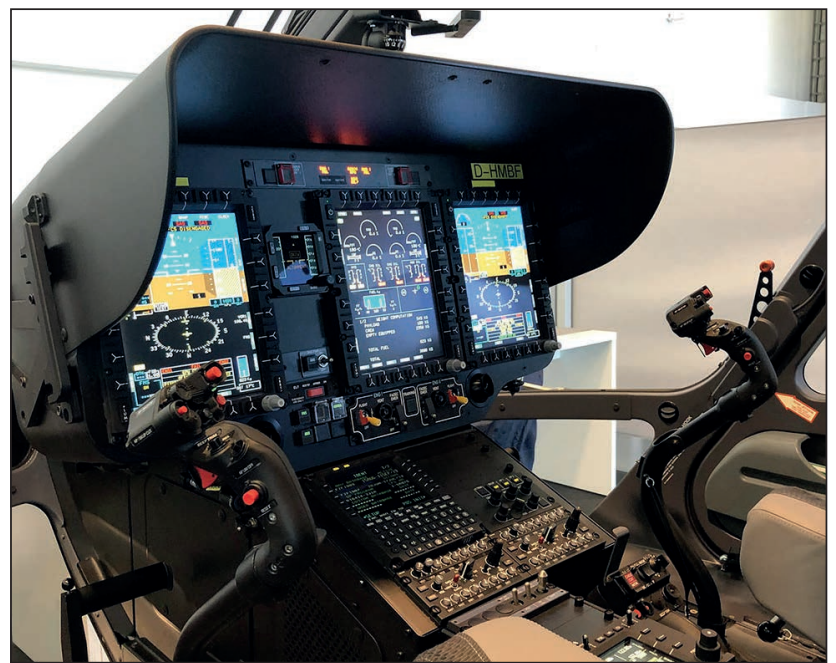

6. ábra. Az Airbus H145M helikopter pilótafülkéje a 6×8 hüvelykes kijelzőkkel [21]

\section{EL/M-2084 RADAROK}

Az EL/M-2084 többfunkciós radar (MMR - Multi-Mission Radar), gallium-nitrid (GaN) alapú félvezetőkből felépített, számítógép által vezérelt, aktív fázisvezérelt antennarácscsal rendelkezik (AESA - Active Electronically Steered Array). Ez azt jelenti, hogy mindegyik elem mellé külön jel-

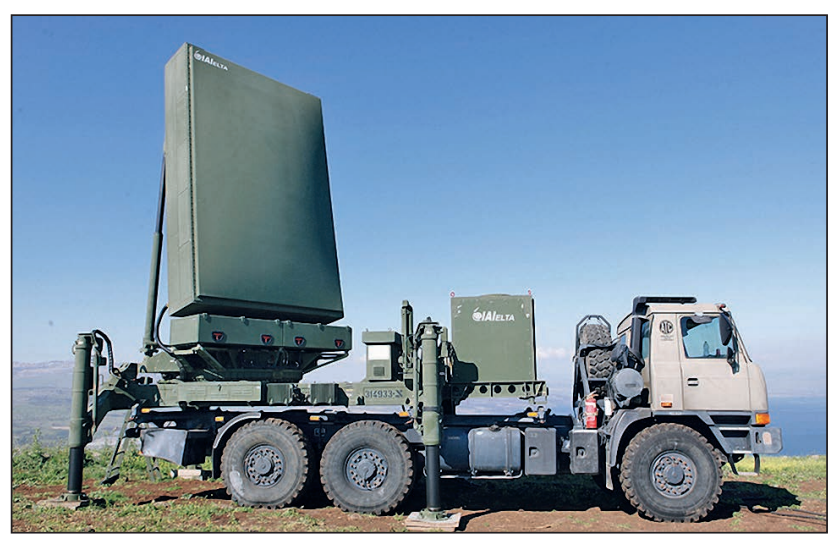

7. ábra. Mobil platformra szerelt EL/M-2084 többfunkciós radar [22]

generátort és erősítőt építettek be, mindegyik antenna önálló jelet sugároz, amely teljesen független a mellette lévőktől. A 2 és $4 \mathrm{GHz}$ közötti S sávban (7,5-15 cm hullámhossz) működő lokátor az ellenség aktív és passzív elektronikai zavarása esetén is hatékonyan biztosítja a 3D-s valós idejű légi helyzetkép rendelkezésre állását. Kiemelkedő hatékonysággal alkalmazható mind a légvédelmi (AD Air Defense) és a tüzérségi fegyver-helymeghatározó (WLR - Weapon Locating Radar) feladatokhoz. AD módban a radar valamennyi típusú légi célpontot felismeri és osztályozza, és valós idejű képet készít a légi helyzetről (ASP - Air Situation Picture). A WLR mód érzékeli a kiváltott aknavetőés tüzérségi lövedékeket és rakétákat, és meghatározza az ellenséges objektumok kilövési helyét, valamint kiszámítja a becsapódási pontot. Ezenkívül a tǔzvédelmi radar (FCR Fire Control Radar) alkalmazása lehetővé teszi a rakétaelhárító rendszerekkel és a légvédelmi rakétákkal (SAM Surface-to-Air Missile) történő együttműködést.

Az EL/M-2084 radarok horizontális lefedettsége $120^{\circ}$-os szektor, vagy körkörös $360^{\circ}$, légi célok megfigyelése, vagy $120^{\circ}$ tüzelési helyzet meghatározása esetén. Gyorsan telepíthetők, mobil radarként is szolgálnak, és a légvédelmi rakétacsapatokat is ellátják információval. Korszerű kialakításuk révén tüzérségi felderítőlokátorként is működhetnek. Rendelkeznek C-RAM (Counter Rocket, Artillery, and Mortar - rakéta, tüzérség és löveg elhárítás) és C-UAV (Counter Unmanned Aerial Vehicle, UAV, azaz pilóta nélküli légijármű-elhárítás) képességekkel is, így gyakorlatilag minden repülőgépet, légi fenyegetést képesek érzékelni, még az alacsonyan repülő UAV-eszközöket is. C-RAM szerepkörbe telepítve, a fegyverrendszerbe integrálva tűzirányítást nyújthatnak, megbízhatóbb és jobb légihelyzet-képet biztosítanak, mint az eddig rendszerben álló radarok, illetve lehetővé teszik bármilyen manőverező repülőgép zavartalan nyomon követését [22]. (7. ábra.)

Az említett példák rámutatnak arra, hogy egy új technikai eszköz rendszerbe állításakor a geoinformációs támogatás fejlesztésével és újragondolásával is számolni kell, amelynek szabályozási hátterét, alapfeltételeit az MH Geoinformációs Támogatási Doktrína teremtheti meg.

\section{ÚJ SZAKUTASÍTÁSOK KIALAKÍTÁSA}

A jelenlegi hatályos doktrína nem minden részletében működik irányelvként, többször szakutasítás szintjén szabja meg a feladatokat. A felülvizsgálatnak ezen túlszabályozás megszűntetése, a NATO felülvizsgálat alatt álló irányelvekkel való további szinkronizálás is feladata. A részletes, szakmai iránymutatásokat külön szakutasításokba kell rendezni, a 
doktrína megújítása után pedig szükség szerint azokat is aktualizálni, modernizálni kell. Ennek a feladatnak az egyik első példája a Katonai tereptan [23] című kiadvány, aminek megújítása lesz az MH Geoinformációs Támogatási Doktrína új verziójának kiadása után az újabb szakmai feladat.

\section{Összegzés}

Az MH Geoinformációs Támogatási Doktrína felülvizsgálata, új doktrína kiadása időszerű. Ezt egyrészt a legutóbbi kiadása óta eltelt időben megvalósult technikai változások, másrészt a nemzeti doktrínákkal és a NATO Térképészeti Irányelveivel történő összehangolás indokolja. A szakmai megújítás az általános felhasználáshoz kialakítandó doktrínán túl megteremti egy biztonság- és védelemföldrajzi elemzéshez alkalmazható, geoinformációs értékelő-elemző rendszer szabályozási keretét. A jelenleg hatályos szakmai doktrína a nemzeti sajátosságok miatt több ponton eltér a NATO irányelveitől, de ezek egy részét meg kell tartani a nemzeti szabályozás hatékonysága érdekében. Az új doktrína kialakításához ki kell tekinteni a szövetségesi rendszerben - NATO, EU - a partnerországok doktrínáira is. Elsősorban a V4 országok, ${ }^{7}$ azon belül is a hazánkkal nagyjából egyező méretü és lehetőségekkel rendelkező Csehország szakmai szabályzójának megismerése bővítheti ismeretünket. Ennek a lehetősége, illetve a megújult MH Geoinformációs Támogatási Doktrínára tett konkrét szakmai javaslatok bemutatása a jelen tanulmány folytatásának tekinthető következő elemzés témája.

A tanulmány az Innovációs és Technológiai Minisztérium Kooperatív Doktori Program Doktori Hallgatói Ösztöndíj Programjának a Nemzeti Kutatási, Fejlesztési és Innovációs Alapból finanszírozott szakmai támogatásával készült.

(Folytatjuk)

\section{HIVATKOZOTT IRODALOM}

[1] Magyar Honvédség, Magyar Honvédség Geoinformációs Támogatási Doktrína, 1. kiadás, Nyt. sz.: Ált/213., 2014.

[2] North Atlantic Military Committee, NATO Geospatial Policy, MC 296/3., 2016.;

[3] NATO Standardisation Office, NATO Allied Joint Doctrine for Geospatial Support, AJP-3.17., 2016.;

[4] Krajnc Zoltán (főszerk.), Hadtudományi lexikon - Új kötet Budapest: Dialóg Campus, 2019.;

[5] NATO Standardisation Agency, NATO Glossary of terms and definitions (English and French), AAP06(2014)., 2014. 2-D-9.;

[6] Mező András, „A Magyar Honvédség doktrínafejlesztése - 1. rész." Hadtudomány 27, 3-4.sz. (2017): 19.;

[7] Mező András, „A Magyar Honvédség doktrínafejlesztése - 2. rész." Hadtudomány 28, 1.sz. (2018): 49.;

[8] Mező András, A katonai stratégiaalkotás és doktrínafejlesztés Magyarországon (PhD értekezés). Budapest: Zrínyi Miklós Nemzetvédelmi Egyetem, 2019, 225. p.

[9] MH Hadkiegészítő, Felkészítő és Kiképző Parancsnokság, Magyar Honvédség Doktrína Hierarchia és Doktrína Fejlesztési Terv (2019-2022), 2019.;

[10] Mező András, „Doktrínafejlesztés a Magyar Honvédségben.” Honvédségi Szemle, 145, 4.sz. (2017): 161. p.;
[11] Mező András, A katonai stratégiaalkotás és doktrínafejlesztés Magyarországon (PhD tézisfüzet). Budapest: Zrínyi Miklós Nemzetvédelmi Egyetem, 2019, 6. p.

[12] NATO Standardisation Office, NATO METOC Support, Allied Joint Doctrine for Meteorological and Oceanographic Support, AJP-3.11., 2016.;

[13] „[HUN] Leopard 2" https://forum.htka.hu/threads/ hun-leopard-2.1568/page-4 (Letöltve: 2021.5.11)

[14] Kelecsényi István, „A harcmezők „nagymacskái” - a Leopard 2-es harckocsicsalád II. rész." Haditechnika 53, 4. sz. (2019): p. 64, https://doi.org/10.23713/ HT.53.4.12;

[15] Ocskay István, „A Lynx harcjárműcsalád fejlesztése, technikai leírása és jövője III. rész." Haditechnika 55, 2. sz. (2021): pp. 56-62 https://doi.org/10.23713/ HT.55.2.11;

[16] Rheinmetall Defence. Lynx Infantry Fighting Vehicle. 2016. https://dtrmagazine.com/wp-content/ uploads/2016/06/Lynx-IFV-Special-Supplement.pdf (Letöltve: 2021.3.29.);

[17] Forrás: https://defense-update.com/20141218 leopard2a7.html (Letöltve: 2021.7.2).

[18] Bali Tamás, "Fegyvernemi kultúraváltás a H145M helikopter hazai rendszerbe állításával” Honvédségi Szemle 149, 1. sz. (2021). https://doi.org/10.35926/HSZ.2021.1.1;

[19] „The "HForce" is with Hungary's H145Ms - Setting a new era for the country's Defence Forces" Airbus, 2020.12.18. https://www.airbus.com/newsroom/ stories/The-HForce-is-with-Hungary-H145M.html (Letöltve: 2021.3.29.);

[20] Airbus, H145M Tecnical Data. 2019. www.airbus.com/content/dam/corporatetopics/ publications/brochures/H145MTD.pdf (Letöltve: 2021.3.29);

[21] Forrás: https://airportal.hu/wp-content/ uploads/2019/09/IMG_2155.jpg (Letöltve: 2021.3.29);

[22] Israel Aerospace Industries, ELM-2084 MMR - Multi Mission Radar. 2019. https://www.iai.co.il/p/ elm-2084-mmr (Letöltve: 2021.3.27.);

[23] Balatoni Béla (szerk.), „Katonai tereptan” Nyt.sz.: Ált/204. Magyar Honvédség Parancsnokság, 1991.

\section{JEGYZETEK}

1 Válságövezetek biztonság- és védelemföldrajzi elemzéséhez alkalmazható geoinformációs értékelő-elemző rendszerek kialakításának lehetősége a Magyar Honvédségben.

2 North Atlantic Military Committee. NATO Geospatial Policy, MC 296/4., 2019.

3 Magyar Honvédség Doktrína Fejlesztési Terv (DOFT).

4 A NATO Egységesítési Egyezményeinek (Standardization Agreement for procedures and systems and equipment components) rövidítése. 5 Mező András alezredes, NATO Transzformációs Parancsnokság. Szakterülete a katonai stratégia és a doktrínafejlesztés.

6 Például: TOPFAS (Tool for Operational Planning, Force Activation and Simulation) - a műveleti tervezéshez és a haderő aktiválásához szükséges adat- és tervezési támogatási rendszer a NATO műveleti tervezési folyamatában; LOGFAS (Logistics Functional Area Services) - a NATO stratégiai mozgáshoz és szállításhoz, többnemzeti bevetéshez, tervezéséhez és végrehajtáshoz, hadszíntéren belüli mozgás ütemezéséhez és a fenntartástervezéshez tartozó logisztikai folyamatokat támogató eszközcsomagja.

7 Visegrádi Együttműködés, Csehország, Lengyelország, Magyarország és Szlovákia regionális szervezete. 